\title{
Artikel
}

\section{Arrest Varkens in Nood: twee richtinggevende uitspraken van de Afdeling bestuursrechtspraak}

\author{
Mr. H.A.J. (Henk) Gierveld*
}

\section{Onderwerp van de bijdrage}

Op 14 januari 2021 heeft het Hof van Justitie van de Europese Unie (hierna: het Hof) arrest gewezen naar aanleiding van een verzoek van de rechtbank Limburg om een prejudiciële beslissing krachtens art. 267 van het Verdrag betreffende de werking van de Europese Unie (VWEU). ${ }^{1}$ Naar anleiding van dat arrest heeft de Afdeling bestuursrechtspraak van de Raad van State (hierna: de Afdeling) twee richtinggevende uitspraken gedaan over de antwoorden van het Hof. Op 14 april 2021 deed zij uitspraak over de vraag bij welke besluiten de voorwaarde van art. 6:13 van de Algemene wet bestuursrecht (Awb) belanghebbenden niet mocht en zou worden tegengeworpen. ${ }^{2} \mathrm{Op} 4$ mei 2021 ging de Afdeling in op de vraag of en in welke gevallen een niet-belanghebbende toegang tot de bestuursrechter zou moeten hebben. ${ }^{3}$ In beide uitspraken maakt de Afdeling haar voorlopige werkwijze bekend. Zij gaat er bij beide onderwerpen van uit dat wetswijziging noodzakelijk is.

In dit artikel wordt (kort) ingegaan op het arrest, maar vooral aandacht besteed aan de twee richtinggevende uitspraken van de Afdeling. Voor een uitgebreide analy-

Mr. H.A.J. Gierveld is als toegevoegd onderzoeker verbonden aan het Utrecht Centre for Water, Oceans and Sustainability Law van de Universiteit Utrecht en is lid van de redactie van het Tijdschrift voor Omgevingsrecht.

1. HvJ EU 14 januari 2021, ECLI:EU:C:2021:7

2. ABRvS 14 april 2021, ECLI:NL:RVS:2021:786.

3. ABRvS 4 mei 2021, ECLI:NL:RVS:2021:953. se van de verwijzingsuitspraak van de rechtbank Limburg $^{4}$ en het arrest van het Hof wil ik verwijzen naar een recent verschenen artikel in het Nederlands Tijdschrift voor Bestuursrecht. ${ }^{5},{ }^{6}$ Voor het zelfstandig kunnen lezen van deze bijdrage wordt hieronder wel de casus weergegeven.

Burgemeester en wethouders van de gemeente EchtSusteren hadden een omgevingsvergunning op grond van de Wet algemene bepalingen omgevingsrecht (Wabo) verleend voor het bouwen van een stal en het houden van meer dan 750 varkens. Art. 3.12, vijfde lid, van de Wabo bepaalt ten aanzien van een dergelijke voorgenomen activiteit dat een ieder zienswijzen naar voren kan brengen over het ontwerpbesluit. Dat had de dierenarts niet gedaan en ook de stichtingen (waaronder de Stichting Varkens in Nood) hadden geen zienswijze naar voren gebracht. Die mogelijkheid was hun simpelweg niet geboden doordat de gemeente geen toepassing had gegeven aan dat Wabo-artikel en ook had nagelaten om een ontwerpvergunning ter inzage te leggen of de zakelijke inhoud weer te geven. Zowel de dierenarts als de stichtingen stelden beroep in bij de rechtbank Limburg. Het beroep van de dierenarts zou, zo oordeelde de bestuursrechter, niet ontvankelijk moeten worden verklaard omdat zij niet belanghebbende is in de zin van art. 1:2 Awb en ten aanzien van de beroepen van de

4. Rb. Limburg 21 december 2018, ECLI:NL:RBLIM:2018:12159

5. H.A.J. Gierveld, Arrest Varkens in Nood: much ado about nothing, NTB 2021/137. In dat artikel is ook een overzicht opgenomen van bloggers, annotatoren en andere schrijvers over de relevante uitspraken.

6. Zie verder de eerder in TO verschenen bijdragen van G.A. van der Veen: Art. 6:13 Awb in de fuik?, TO 2020, afl. 4, p. 77-79 en Art. 6:13 Awb in nood, TO 2021, afl. 1, p. 3-6. 
stichtingen zou met art. 6:13 Awb in de hand geconcludeerd kunnen worden dat de belanghebbende stichtingen niet verweten kon worden geen zienswijzen naar voren te hebben gebracht. De rechtbank Limburg meende echter dat een uitleg van het Verdrag van Aarhus (hierna ook: verdrag) door het Hof noodzakelijk was om te kunnen beslissen in het haar voorgelegde geschil.

Inmiddels heeft de rechtbank Limburg einduitspraak gedaan. De beroepen van de stichtingen zijn gegrond bevonden, met als gevolg dat de omgevingsvergunning is vernietigd. Het beroep van de dierenarts is niet ontvankelijk verklaard, niet omdat zij niet-belanghebbende was, maar omdat nu in de beroepszaak van de stichtingen de vergunning toch al werd vernietigd, zij geen procesbelang meer had bij de beoordeling van haar beroep. ${ }^{7}$

\section{De vragen van de rechtbank Limburg}

In de zaak van de dierenarts komt de rechtbank tot de voorlopige conclusie dat het beroep van de dierenarts niet ontvankelijk is: zij is naar Nederlands recht geen belanghebbende. Maar de rechtbank ziet ook dat de inspraakprocedure gebrekkig is verlopen. De rechtbank stelt naar aanleiding daarvan de vraag of art. 9, tweede lid, zo zou moeten worden uitgelegd dat hieruit voortvloeit dat het publiek bij gestelde schending van voor dit publiek geldende procedurele vereisten en inspraakrechten, zoals opgenomen in art. 6 van het verdrag, toegang tot de rechter dient te hebben. De beantwoording van de vraag is niet eenvoudig, omdat de rechtbank in haar vraag uitging van de - later gebleken niet juiste - anname dat art. 6 inspraakrechten toekent aan een ieder.

Twee van de vragen van de rechtbank gaan over de toegang van een niet-belanghebbende tot de rechter, waarbij de rechtbank de bestuursrechter bedoelt, de rechtbank ziet geen rol weggelegd voor de civiele rechter. ${ }^{8}$ De vier andere vragen hebben betrekking op de vraag of de toegang tot de bestuursrechter afhankelijk mag worden gesteld van het naar voren hebben gebracht van een zienswijze (art. 6:13 Awb).

\section{De relevante bepalingen van het Verdrag van Aarhus}

Het $\operatorname{Hof}^{9}$ gaat in zijn arrest allereerst in op art. 6 van het verdrag, dat als opschrift 'Inspraak in besluiten over specifieke activiteiten' kent. Daarin wordt voor-

7. Rb. Limburg 23 april 2021, ECLI:NL:RBLIM:2021:3600.

8. Uitgebreid over de volwaardige rol van de civiele rechter: Gierveld 2021. Zie ook Rb. Limburg 23 april 2021, ECLI:NL:RBLIM:2021:3600, r.o. 8.

9. Uitgebreider in de conclusie van A-G Bobek van 2 juli 2020, ECLI:EU:C: 2020:541. geschreven dat elke verdragspartij de in dat artikel opgesomde inspraakbepalingen toepast ten aanzien van besluiten over het al dan niet toestaan van voorgestelde activiteiten vermeld in bijlage I. ${ }^{10}$ Dat zijn allemaal zware milieubesluiten. ${ }^{11}$ Daarnaast moeten de verdragspartijen de bepalingen ook toepassen op andere besluiten die een aanzienlijk effect op het milieu kunnen hebben. ${ }^{12}$ Het Hof komt tot de conclusie dat hoewel in art. 6 de term 'publiek' herhaaldelijk wordt gebruikt, uit lezing van het artikel in zijn geheel blijkt dat het alleen van toepassing is op het 'betrokken publiek'. ${ }^{13}$ Het verdrag bepaalt dat alleen voor het betrokken publiek inspraak in het besluitvormingsproces open moet staan.

Art. 9 van het verdrag gaat over de toegang tot de rechter. In het tweede lid staat dat gewaarborgd moet zijn dat leden van het betrokken publiek die een voldoende belang hebben dan wel stellen dat inbreuk is gemaakt op een recht, toegang hebben tot de rechter om de materiële en formele rechtmatigheid te bestrijden van enig besluit, handelen of nalaten vallend onder de bepalingen van art. 6 van het verdrag. Het derde lid stelt dat 'aanvullend op en onverminderd' de onder meer in het tweede lid bedoelde herzieningsprocedures, elke verdragspartij waarborgt dat leden van het publiek, wanneer zij voldoen aan de eventuele in haar nationale recht neergelegde criteria, toegang hebben tot bestuursrechtelijke of rechterlijke procedures ${ }^{14}$ om het handelen en nalaten van privépersonen en overheidsinstanties te betwisten die strijdig zijn met bepalingen van haar nationale recht betreffende het milieu.

\section{Het arrest Varkens in Nood}

Op de eerste en tweede vraag van de rechtbank Limburg geeft het Hof een tweeledig antwoord:

1. Artikel 9, tweede lid, van het Verdrag van Aarhus verzet zich er niet tegen dat de leden van het publiek als zodanig geen toegang tot de rechter hebben om op te komen tegen een Aarhus-besluit; ${ }^{15}$

2. Artikel 9, derde lid, van het verdrag verzet zich er wel tegen dat deze personen geen toegang tot de rechter kunnen hebben om zich te beroepen op ruimere rechten op inspraak in het besluitvormings-

10. Art. 6 lid 1 onder a van het verdrag.

11. Met andere woorden om activiteiten die opgenomen zijn in bijlagen bij richtlijn 2010/75/EU (RIE) en richtlijn 2011/92/EU (mer-richtlijn).

12. Art. 6 , eerste lid, onder b.

13. HvJ EU 14 januari 2021, ECLI:EU:C:2021:7, r.o. 39. Zie ook A-G Bobek in r.o. 118: 'In het licht van het voorgaande geef ik in overweging dat artikel 6 van het Verdrag van Aarhus, artikel 6 van richtlijn 2011/92 en artikel 24 van richtlijn 2010/75 aldus moeten worden uitgelegd dat zij alleen volledige inspraakrechten verlenen aan "het betrokken publiek" in de zin van deze rechtsinstrumenten, maar niet aan "het publiek" in zijn geheel.'

14. Om verwarring te voorkomen over de zinsnede 'bestuursrechtelijke of rechterlijke procedures', geef ik ook de Engelse (authentieke) tekst: administrative or judicial procedures. Met bestuursrechtelijke procedure wordt dus niet de procedure bij de bestuursrechter bedoeld.

15. Dat zijn de besluiten als bedoeld in art. 6, eerste lid, onder a en b van het verdrag. 
proces die alleen door het nationale milieurecht van een lidstaat worden verleend.

Ook in zijn antwoord op de derde tot en met zesde vraag komt het Hof met een tweeledig antwoord:

1. Artikel 9, tweede lid, van het verdrag verzet zich ertegen dat de ontvankelijkheid van het beroep in rechte, dat wordt ingesteld door het betrokken publiek, afhankelijk wordt gesteld van deelname aan de voorbereidingsprocedure voor het bestreden besluit, ook al is deze voorwaarde niet van toepassing wanneer redelijkerwijs niet kan worden verweten dat daaraan niet is deelgenomen.

2. Artikel 9, derde lid, van het verdrag verzet zich er niet tegen dat de ontvankelijkheid van een daarin bedoeld beroep in rechte afhankelijk wordt gesteld van de deelname van de verzoeker aan de voorbereidingsprocedure voor het bestreden besluit, tenzij hem, gelet op de omstandigheden van de zaak, redelijkerwijs niet kan worden verweten dat hij hier niet aan heeft deelgenomen.

Mij leek (onvoltooid verleden tijd) dat met het arrest in de hand:

1. het beroep van een niet-belanghebbende tegen een Aarhus-besluit niet ontvankelijk moet worden verklaard (het Nederlandse recht maakt dat overigens niet anders voor niet-Aarhus-besluiten);

2. de civiele rechter bevoegd is om te oordelen over de schending van nationaalrechtelijke toegekende inspraakrechten, zoals art. 3.12, vijfde lid, van de Wabo. De bestuursrechter loopt in art. 8:1 Awb aan tegen zowel het slot van de belanghebbende als dat van het besluit;

3. art. 6:13 Awb niet tegengeworpen mag worden aan belanghebbenden die geen zienswijzen naar voren hebben gebracht tegen een ontwerp Aarhus-besluit.

Het is duidelijk dat de Afdeling andere conclusies trekt uit de antwoorden van het Hof en besloten heeft om twee - in haar woorden - richtinggevende uitspraken te doen. Op 14 april 2021 ging zij in op de vraag bij welke besluiten de voorwaarde van art. 6:13 Awb belanghebbenden niet mocht en zou worden tegengeworpen. ${ }^{16}$ Deze uitspraak wordt in paragraaf 5 besproken. In paragraaf 6 behandel ik de uitspraak van 4 mei 2021, waarin de Afdeling inging op de vraag of en in welke gevallen een niet-belanghebbende toegang tot de bestuursrechter zou moeten hebben. ${ }^{17}$ In beide uitspraken maakt de Afdeling haar voorlopige werkwijze bekend. Zij gaat er bij beide onderwerpen van uit dat wetswijziging noodzakelijk is.

\section{De uitspraak van de Afdeling van 14 april 2021}

In haar persbericht bij de uitspraak benadrukt de Afdeling dat het arrest Varkens in Nood een wetswijziging van art. 6:13 Awb noodzakelijk maakt, omdat wat in art. 6:13 Awb is bepaald in zoverre voor belanghebbenden bij Aarhus-besluiten niet in overeenstemming is met art. 9, tweede lid, van het verdrag en dus aanpassing behoeft door de wetgever. ${ }^{18}$ Reden voor de Afdeling om zolang zo'n wijziging er nog niet is, te willen voorzien in een oplossing. De Afdeling constateert dat het buitengewoon lastig is om te achterhalen of er sprake is van een Aarhus-besluit, zij spreekt van een voor de rechtspraktijk onwerkbare situatie. Toch is die kwalificatie wel nodig om te bepalen of art. 6:13 Awb buiten toepassing kan worden gelaten vanwege strijd met art. 9, tweede lid, van het verdrag. Immers, art. 6:13 Awb blijft waar het niet gaat om een Aarhus-besluit gewoon van kracht, hetgeen - zo lees ik dat - door de Afdeling niet wordt onderschreven. Dat het kwalificeren veel tijd en energie kost, mag zo zijn, maar kan geen argument zijn om art. 6:13 Awb buiten toepassing te laten bij alle omgevingsrechtelijke besluiten die voorbereid zijn met de uniforme openbare voorbereidingsprocedure (uov):

'In afwachting van een oplossing door de wetgever kiest de Afdeling daarom voor een uit oogpunt van rechtsbescherming ruimhartige uitleg van het verdrag, vooral ook om te verzekeren dat het uit het verdrag voorvloeiende recht op toegang tot de rechter niet een te beperkte invulling krijgt. Daarom zal in alle gevallen waarin in omgevingsrechtelijke zaken de uitgebreide openbare voorbereidingsprocedure is toegepast, art. 6:13 van de Awb niet worden tegengeworpen aan belanghebbenden. Daarbij beschoumt de Afdeling als omgevingsrechtelijke zaken de zaken over besluiten op grond van de Wet algemene bepalingen omgevingsrecht, Wet milieubeheer, Wet ruimtelijke ordening, Tracéwet, Wet geluidhinder, Wet natuurbescherming, Ontgrondingenwet, Waterwet, Wet bodembescherming, Wet luchtvaart, Mijnbouwwet, Kernenergiewet, Wet inzake de luchtverontreiniging, Wet bescherming Antarctica en andere wetten en regelingen op het gebied van het milieu en de ruimtelijke ordening.'

\subsection{Een aantal kanttekeningen}

Art. 9, tweede lid, juncto art. 6, eerste lid, van het verdrag heeft betrekking op besluiten met (mogelijk) aanzienlijk effect voor het milieu. De meeste omgevingsrechtelijke zaken (ruimtelijke ordening, natuur, water en milieu) hebben geen en zelfs geen mogelijk aanzienlijk effect op het milieu. Het is verder verwarrend dat de

18. Art. 6:13 Awb luidt: 'Geen beroep bij de bestuursrechter kan worden ingesteld door een belanghebbende aan wie redelijkerwijs kan worden verweten dat hij geen zienswijzen als bedoeld in artikel 3:15 naar voren heeft gebracht, geen bezwaar heeft gemaakt of geen administratief beroep heeft ingesteld.' 
Afdeling de term 'uitgebreide openbare voorbereidingsprocedure' gebruikt, die sinds 1 juli 2005 niet meer bestaat. Bedoeld zal zijn de uniforme openbare voorbereidingsprocedure (uov).

De Afdeling zoekt aansluiting bij de opsomming van de wetten in art. 13.1 van de Wet milieubeheer $(\mathrm{Wm})$, om die vervolgens aan te vullen met een aantal andere wetten. Het lijstje in art. $13.1 \mathrm{Wm}$ is verouderd, immers voor het van toepassing zijn van afdeling $13.2 \mathrm{Wm}$ moet die afdeling genoemd worden in de betreffende wet. Maar in de genoemde Wabo, de Waterwet, de Wet inzake de luchtverontreiniging en de Wet geluidhinder wordt afdeling $13.2 \mathrm{Wm}$ niet van toepassing verklaard. Ook om een andere reden lijkt het niet zo verstandig om bij het onderzoeken van de gevolgen van het arrest de Kernenergiewet, de Wet inzake de luchtverontreiniging (kent overigens geen toepassing van afdeling 3.4 Awb meer), de Wet geluidhinder en de Wet bescherming Antarctica te noemen. Dat zijn niet de wetten die op het netvlies staan als het gaat om conclusies naar aanleiding van het arrest Varkens in Nood. ${ }^{19}$ De Afdeling geeft zelf aan dat de lijst niet limitatief is. Wat opvalt is dat bijvoorbeeld de Mijnbouwwet wel wordt genoemd, maar de Elektriciteitswet 1998 en de Gaswet ontbreken. Vanuit het perspectief van de Afdeling hoeft de lijst wellicht niet limitatief te zijn, maar dat maakt het voor de bestuursorganen wel lastig om in de kennisgeving van het ontwerpbesluit al dan niet te wijzen op de noodzaak van het naar voren brengen van een zienswijze. ${ }^{20}$

De (door mij) gecursiveerde passage is verwarrend. Waarschijnlijk heeft de Afdeling niet overzien wat de gevolgen zijn van de overweging dat alle zaken over besluiten op grond van de omgevingswetten omgevingsrechtelijk zijn. En dat klopt ook niet: in veel van de genoemde wetten zijn ook uov-besluiten opgenomen die niet omgevingsrechtelijk van aard zijn en al helemaal geen Aarhus-besluiten zijn. Dat speelt met name bij de uitvoeringsvergunningen op grond van de Wet ruimtelijke ordening, Tracéwet, Waterwet, Gaswet, Elektriciteitswet 1998 en Mijnbouwwet.

\subsection{Voorstel voor een andere praktische werkwijze}

Was het niet beter geweest om binnen het omgevingsrecht de daarin voorkomende besluiten in drie groepen te verdelen: (a) Aarhus-besluiten, (b) geen Aarhusbesluiten en (c) besluiten waarbij twijfel kan ontstaan of er sprake is van een Aarhus-besluit? Bij categorie b, de grootste groep van de omgevingsrechtelijke zaken, is er veel voor te zeggen dat de bestuursrechter art. 6:13 Awb niet eens buiten toepassing kán verklaren. Afgaand op de omschrijving in de zaak van het Almelose bestem- mingsplan 'Haghoek Rosarium Westeres' is dat bestemmingsplan geen Aarhus-besluit en was deze kwalificatie ook niet lastig of ingewikkeld.

Daarentegen is er bij de categorie a- en c-besluiten alle respectievelijk meer reden om beroepen inhoudelijk te gaan behandelen als er geen zienswijzen naar voren zijn gebracht. Met name bij categorie c lijkt me dat het door de Afdeling terecht gesignaleerde probleem om een besluit te kwalificeren als Aarhus-besluit een juridisch goede reden kan zijn om bij die besluiten geen toepassing te geven aan art. 6:13 Awb 'om te verzekeren dat het uit het verdrag voorvloeiende recht op toegang tot de rechter niet een te beperkte invulling krijgt'.

\subsection{Kamervragen}

Op 22 april 2021 zijn door Tweede Kamerleden Koerhuis en Minhas (beiden VVD) vragen ${ }^{21}$ gesteld naar aanleiding van een artikel in Het Financieele Dagblad met als titel 'Vertraging woningbouw dreigt na uitspraak Raad van State'. ${ }^{22}$ In dat artikel staat onder meer dat overheden, projectontwikkelaars en bouwers vanaf nu moeten rekenen op extra vertraging bij hun plannen voor windparken, wegen en woningen, omdat de Afdeling de toegang tot de rechter heeft verruimd. Minister Ollongren heeft op 17 mei 2021 de Tweede Kamer een brief gestuurd waarin uitstel van de beantwoording van de Kamervragen is aangekondigd. Zij geeft aan dat voor beantwoording meer tijd nodig is vanwege interdepartementaal overleg met de ministeries van Justitie en Veiligheid (JenV), Landbouw, Natuur en Voedselkwaliteit (LNV), Economische Zaken en Klimaat (EZK) en Infrastructuur en Waterstaat (IenW). ${ }^{23}$

\subsection{Conclusie naar aanleiding van de uitspraak van 14 april 2021}

Uit het arrest Varkens in Nood volgt dat art. 6:13 Awb niet mag worden tegengeworpen aan belanghebbenden die om welke reden dan ook geen zienswijze naar voren hebben gebracht over het ontwerp Aarhus-besluit. Het zal in bepaalde gevallen lastig zijn om te bepalen of er sprake is van een Aarhus-besluit. Maar dat mag geen reden zijn om in een uitspraak te bepalen dat in alle besluiten op grond van genoemde en niet-genoemde omgevingswetten belanghebbenden art. 6:13 Awb niet zal worden tegengeworpen.

De door de Afdeling aangekondigde praktische werkwijze makt het misschien voor de bestuursrechter eenvoudiger, maar voor bestuursorganen zorgt de werkwijze voor weinig duidelijkheid en langere onzekerheid over de onherroepelijkheid van besluiten.
19. Met de komst van de Omgevingswet wordt de Wm ingrijpend gewijzigd. In art. 13.1 lid 2 Wm worden dan alleen nog maar de Kernenergiewet, de Wet geluidhinder, de Wet bodembescherming en de Wet bescherming Antarctica genoemd, Kamerstukken II 2017/18, 34 986, nr. 2, p. 406-407.

20. Zie ook art. 3:45 Awb, waarin staat dat bij bekendmaking en mededeling van het besluit wordt aangegeven wie beroep kunnen instellen.
21. Kamervragen $2021 Z 006758$, te vinden op www.tweedekamer.nl.

22. Zie https://fd.nl/economie-politiek/1380821/vertraging-woningbouwdreigt-na-uitspraak-raad-van-state-jud1 cavesmdK.

23. Brief van 17 mei 2021, kenmerk 2021-00000210532021-0000263820, te vinden op www.tweedekamer.nl. 


\section{De uitspraak van de Afdeling van 4 mei 2021}

Ook bij deze richtinggevende uitspraak verscheen een persbericht met een daarin opgenomen schema over de werkwijze van de Afdeling in afwachting van een wetswijziging.

\subsection{De toegang van de niet-belanghebbende tot de rechter (Hof)}

Het is zonneklaar dat het arrest Varkens in Nood noodzaakt tot een wijziging van art. 6:13 Awb. Maar dat het arrest volgens de Afdeling ook noodzaakt tot een wijziging van art. 8:1 Awb-al wordt dat niet met zoveel woorden gezegd - is opmerkelijk.

In art. $267 \mathrm{VWEU}$ is niet alleen neergelegd dat het Hof bevoegd is om bij wijze van prejudiciële beslissing een uitspraak te doen over onder andere de uitlegging van de verdragen, maar ook dat het verzoek noodzakelijk is 'voor het wijzen van haar vonnis'. Dat had onder meer tot gevolg dat het Hof niet inging op de vraag van de rechtbank Limburg naar de onderdelentrechter. ${ }^{24} \mathrm{Zo}$ ook werd in het dictum alleen ingegaan op de positie van de non-gouvernementele organisaties, omdat er in de casus geen ander lid van het betrokken publiek dan de drie (milieu)stichtingen beroep had ingesteld. ${ }^{25} \mathrm{Uit}$ de bewoordingen van het arrest mag wel worden afgeleid, zoals de Afdeling doet in haar uitspraak van 14 april, dat het oordeel van het Hof over toegang tot de rechter bij Aarhus-besluiten niet alleen geldt voor non-gouvernementele organisaties, maar voor het betrokken publiek in het algemeen. Het Hof spreekt zich, zoals gezegd, daar niet over uit omdat het in de hem voorgelegde casus alleen gaat om het beroep van een non-gouvernementele organisatie.

Het is dan bijzonder vreemd dat de Afdeling in het arrest leest dat een niet-belanghebbende die een zienswijze naar voren heeft gebracht, toegang tot de bestuursrechter zou moeten hebben. In de Limburgse casus ging het niet om een beroep dat was ingesteld door een niet-belanghebbende die een zienswijze naar voren had gebracht. Dat betekent dat als de rechtbank daarover een vraag had gesteld, het Hof ook die vraag niet in behandeling had genomen.

24. Zie HvJ EU 14 januari 2021, ECLI:EU:C:2021:7, r.o. 68: 'Tot slot hoeft niet te worden vastgesteld of artikel 9, leden 2 en 3, van het Verdrag van Aarhus zich ertegen verzet dat alleen grieven die betrekking hebben op dezelfde onderdelen van het bestreden besluit als die waarover de verzoeker in de voorbereidingsprocedure opmerkingen heeft ingediend, voor de rechter kunnen worden betwist, aangezien verzoekers in de hoofdgedingen hoe dan ook niet hebben deelgenomen aan die procedure.'

25. Zie de terechte uitbreiding in de ABRvS-uitspraak van 14 april 2021: 'De Afdeling leidt uit de bewoordingen van het arrest van het Hof, in het bijzonder de punten 58 tot en met 60 van het arrest, af dat het oordeel van het Hof over toegang tot de rechter bij besluiten die binnen de werkingssfeer van art. 6 van het verdrag vallen (hierna: "Aarhus-besluiten") niet alleen geldt voor non-gouvernementele organisaties, maar voor "het betrokken publiek" in het algemeen.'
6.2 De toegang van de niet-belanghebbende tot de bestuursrechter (Afdeling)

De Afdeling begrijpt het oordeel van het Hof zo dat wanneer het nationale milieurecht aan een ieder het recht geeft zienswijzen over een ontwerpbesluit naar voren te brengen, art. 9, derde lid, van het verdrag zich ertegen verzet dat leden van het publiek die een zienswijze hebben ingediend de toegang tot de rechter wordt onthouden.

In haar persbericht bij de uitspraak zegt de Afdeling het zo:

'In het "Varkens in Nood"-arrest bepaalde het Europese Hof onder meer dat "leden van het publiek" toegang tot de rechter moeten kunnen krijgen als zij eerder gebruik hebben gemaakt van ruimere inspraakrechten bij besluiten over milieuaangelegenheden.'

Die passage heb ik niet kunnen vinden.

Het Hof zegt alleen maar dat art. 9, derde lid, van het verdrag zich ertegen verzet dat leden van het publiek op geen enkele wijze toegang tot de rechter kunnen krijgen om zich te beroepen op door het nationale milieurecht van een lidstaat verleende ruimere rechten op inspraak in het besluitvormingsproces. Daar staat naar mijn mening niet meer dan dat er uiteraard een rechter moet zijn bij wie je terechtkunt als je niet kunt inspreken waar het nationale recht dat heeft mogelijk gemaakt. Het Unierecht kent geen inspraakrechten toe aan het publiek, maar het verdrag verzet zich niet tegen het geven van inspraakrechten aan een ieder, zoals dat in Nederland brede toepassing heeft gevonden. Maar het is dan ook aan het nationale recht om in dergelijke situaties de nationale inspraakrechten te beschermen. Het Hof stelt dat voor de in art. 9, derde lid, bedoelde beroepen voorwaarden kunnen worden opgenomen waaraan moet worden voldaan om dergelijke beroepen in te stellen, waarbij wel voorkomen moet worden dat door het opleggen van dergelijke criteria bepaalde categorieën 'leden van het publiek' elk recht van beroep wordt ontzegd. Nederland heeft naar mijn mening met art. 8:1 Awb toegestane voorwaarden gesteld (je moet belanghebbende zijn en het moet gaan om een besluit) die tot gevolg hebben, dat - al dan niet onder nadrukkelijke vermelding van art. 8:71 $\mathrm{Awb}^{26}$ - het publiek altijd terechtkan bij de civiele rechter om op te komen tegen schending van bijvoorbeeld de in art. 3.12, vijfde lid, van de Wabo neergelegde rechten.

6.3 De gevolgen van de uitspraak van 4 mei 2021 De gevolgen zijn groot en worden door de Afdeling naar ik vermoed zwaar onderschat. Daar waar verzet nog mogelijk is, zal dat worden ingediend door niet-belanghebbenden die een zienswijze hebben ingediend en van

26. Art. 8:71 Awb: 'Voor zover uitsluitend een vordering bij de burgerlijke rechter kan worden ingesteld, wordt dit in de uitspraak vermeld. De burgerlijke rechter is aan die beslissing gebonden.' 
wie het beroep niet ontvankelijk is verklaard. ${ }^{27}$ Ook rechtbanken zullen uitvoering moeten geven aan de beleidslijn van de Afdeling.

In een uitspraak van 12 mei 2021 voert de raad van de gemeente Gouda aan dat het beroep van de Vereniging Belanghebbenden Turfmarktkerk en het Klooster niet ontvankelijk is omdat de vereniging geen feitelijke werkzaamheden verricht met het oog op de behartiging van haar doelstelling. De Afdeling gaat daar helemaal niet op in. $\mathrm{Zij}$ stelt slechts vast dat de vereniging een zienswijze heeft ingediend tegen het ontwerpbestemmingsplan en dat om die reden het beroep van de vereniging ontvankelijk is. ${ }^{28}$ De Afdeling wijdt geen overweging aan haar eerdere oordeel dat een vereniging geen belanghebbende is (en dus om die reden geen toegang heeft tot de bestuursrechter) als zij louter in rechte opkomt tegen besluiten en geen feitelijke werkzaamheden ontplooit. ${ }^{29}$ Maar het gevolg is wel dat de facto de eis van het moeten verrichten van feitelijke werkzaamheden niet meer bepalend is voor de toegang tot de bestuursrechter: het naar voren hebben gebracht van een zienswijze over het ontwerpbesluit is voldoende.

De bestuursrechter heeft zich, voor zover ik heb gezien, nog niet gebogen over de vraag of een appellant of eiser die geen gevolgen van enige betekenis zal ondervinden doordat hij op een te grote afstand van bijvoorbeeld een windmolen of mestbassin woont en dus geen belanghebbende $\mathrm{e}^{30}$ is, toch wordt toegelaten tot de bestuursrechter omdat hij een zienswijze heeft ingediend. Mij lijkt dat de bestuursrechter de nietbelanghebbende die een zienswijze heeft ingediend niet moet toelaten als de niet-belanghebbende geen gevolgen van enige betekenis zal ondervinden.

Vooral bij projecten als aanleg van wegen en windmolenparken en de uitbreiding van luchthavens is er vaak sprake van grote maatschappelijke weerstand. Ik sluit niet uit dat er vanuit tal van bewonersgroepen en milieuverenigingen massaal opgeroepen wordt om zienswijzen in te dienen. Daar is niks mee mis, daar wordt ook nu vaak gebruik van gemaakt. Maar het gevolg van de uitspraak van 4 mei 2021 is dat er met het ingediend hebben van een zienswijze geen beletsel meer is voor al die niet-belanghebbenden om beroep in te stellen bij de Afdeling. Via crowdfundingacties zullen de griffiegelden wel worden geregeld. Met als gevolg dat de Afdeling per beroepsgrond moet bezien of het relativiteitsvereiste niet roet in het eten van de niet-belanghebbende gooit. Door de uitleg van de Afdeling van 4 mei 2021 kan er voor de Afdeling een onwerkbare situatie

27. ABRvS 14 april 2021, ECLI:NL:RVS:2021:791 (Klooster van Rilland).

28. ABRvS 12 mei 2021, ECLI:NL:RVS:2021:1022 (Gouda).

29. ABRvS 1 oktober 2008, ECLI:NL:RVS:2008:BF3912 (Stichting Openbare Ruimte).

30. Gevolgen van enige betekenis ontbreken indien de gevolgen wel zijn vast te stellen, maar de gevolgen van de activiteit voor de woon-, leefof bedrijfssituatie van betrokkene dermate gering zijn dat een persoonlijk belang bij het besluit ontbreekt. Zie ABRvS 23 augustus 2017, ECLI:NL:RVS:2017:2271 (mestbassin Mechelen), waarnaar in vele uitspraken wordt verwezen. ontstaan: er kan wel heel veel zand in de machine worden gestrooid.

Het gevolg van beide richtinggevende uitspraken samen bezien is dat zowel een vereniging die louter in rechte actievoert als een vereniging die ook feitelijke werkzaamheden ontplooit in beginsel toegang heeft tot de bestuursrechter. Waarbij de eerste vereniging wel een zienswijze naar voren moet brengen en de laatstgenoemde vereniging dat kan overslaan.

\subsection{Kamervragen}

Bij brief van 19 mei 2021 hebben de vaste commissies voor IenW en EZK/LNV minister Ollongren gevraagd om een appreciatie van het kabinet over de uitspraak van 4 mei 2021 en aan te geven welke impact het kabinet verwacht van deze uitspraak:

'Zowel voor de juridische werkbaarheid van het gehele stelsel (dat immers uitging van beperkte mogelijkheden om als niet-belanghebbende beroep en bezwaar in te dienen) als over de extra werklast bij overheden en de rechtspraak. Welke extra inzet wordt voorzien als gevolg van deze uitspraak? 31

\subsection{Wie hebben sinds 4 mei 2021 toegang tot de bestuursrechter?}

Een chronologisch overzicht:

- In de periode van 1 juli 2005 tot 14 januari 2021 konden alleen belanghebbenden die een zienswijze naar voren hadden gebracht over het ontwerpbesluit en belanghebbenden die om verschoonbare redenen geen zienswijze naar voren hadden gebracht bij de bestuursrechter opkomen tegen een besluit.

- Het arrest Varkens in Nood zette de deur na 14 januari 2021 op een kier: ook belanghebbenden die om welke reden dan ook geen zienswijze naar voren hadden gebracht over een ontwerp Aarhusbesluit werden welkom geheten.

- Met de uitspraak van de Afdeling van 14 april 2021 werd de deur nog verder opengezet: een warm welkom voor belanghebbenden die om welke redenen dan ook geen zienswijze naar voren hadden gebracht over een ontwerpbesluit op grond van een tiental door de Afdeling genoemde omgevingsrechtelijke wetten en een aantal niet genoemde wetten.

- Met de uitspraak van de Afdeling van 4 mei 2021 wordt het hek van de dam gehaald. $\mathrm{Nu}$ mogen ook niet-belanghebbenden die een zienswijze hebben ingediend over een ontwerpbesluit op grond van in ieder geval een aantal door de Afdeling genoemde omgevingsrechtelijke wetsartikelen zich melden bij de bestuursrechter.

Het gaat om een tijdelijke werkwijze van de Afdeling die uiteraard ook gevolgd zal worden door de andere bestuursrechters. Van de wetgever worden wijzigingen van art. 6:13 Awb en ten aanzien van art. 8:1 Awb ver-

31. Brief van 19 mei 2021, 168165.01.U (voortgang van de implementatie van de Omgevingswet). 
wacht. De werkwijze zal ongetwijfeld voordelen bieden voor de Afdeling, maar voor de bestuursorganen wordt het wel lastig. Alleen al om overeenkomstig art. 3:45 Awb bij de bekendmaking en bij de mededeling van het besluit te vermelden wie beroep kan instellen. Het zal ongetwijfeld leiden tot vele beroepen op art. 6:11 Awb over de verschoonbare termijnoverschrijding.

\subsection{Conclusie naar aanleiding van de uitspraak van 4 mei 2021}

De wetgever moet - zo lees ik dat - van de Afdeling aan de slag met het opnieuw optuigen van een getrapte actio popularis als codificatie van de voorlopige werkwijze. In het begin van deze eeuw is niet na één nacht ijs besloten om de actio popularis af te schaffen. De reden voor de afschaffing van de actio popularis was niet zozeer gelegen in de verwachting dat dit zou leiden tot een omvangrijke afname van het beroep bij de rechter, maar vooral in het willen voorkomen van procedures tegen overheidsbesluiten zonder dat de procederende partij een belang heeft dat rechtstreeks bij dat besluit is betrokken. 'Dit klemt te meer nu een dergelijke voorziening ook fundamenteel afwijkt van de in artikel 1:2 Awb neergelegde basisregel dat toegang tot de administratieve rechter slechts behoort open te staan voor belanghebbenden, inclusief belangenorganisaties die voldoen aan de vereisten van artikel 1:2, derde lid, Awb. ${ }^{32}$ Het getrapte karakter - het verplicht gebruik maken van de voorbereidingsprocedure - werd behouden en onderdeel van de verbreding van art. 6:13 Awb, maar die eis gold alleen voor belanghebbenden.

Door deze 'eis' van de Afdeling wordt de wetgever gedwongen om terug te komen op de door hem in parlementaire stukken uitgebreid onderbouwde afschaffing van de (getrapte) actio popularis. De Afdeling heeft blijkbaar geen boodschap aan de wens van de wetgever - neergelegd in de Awb - om procedures te voorkomen van partijen die geen rechtstreeks belang hebben bij een besluit.

\section{De wetswijzigingen}

In het genoemde NTB-artikel heb ik voorgesteld om aan art. 6:13 Awb een lid toe te voegen, waarin komt te staan dat het (eerste lid) niet van toepassing is indien beroep wordt ingesteld tegen een besluit waarvoor bij wettelijk voorschrift als bedoeld in art. 3:15, tweede lid, is bepaald dat zienswijzen naar voren kunnen worden gebracht door eenieder. Met een dergelijke aanpassing wordt het bestuursorgaan duidelijkheid geboden bij het opstellen van de kennisgeving voor het ontwerpbesluit, weet de bestuursrechter in welke zaken geen 6:13-ontvankelijkheidstoets behoeft te worden verricht, en kan het tijdrovende en lastige onderzoek of er sprake is van een Aarhus-besluit achterwege blijven. Een dergelijke wijziging kan worden gezien als een gedeeltelijke codifi-

32. Kamerstukken II 2003/04, 29 421, nr. 3, p. 3-8. catie van de door de Afdeling in haar uitspraak van 14 april 2021 voorgestelde tijdelijke werkwijze.

De wijziging die nodig is om een niet-belanghebbende die een zienswijze heeft ingediend toegang te geven tot de bestuursrechter heeft veel meer voeten in de aarde. Gekozen zou kunnen worden om in verschillende sectorale wetten een artikel op te nemen waarin staat dat 'in afwijking van artikel 8:1 Awb' een niet-belanghebbende die een zienswijze naar voren heeft gebracht beroep kan instellen bij de bestuursrechter. ${ }^{33}$

Het is de vraag of het kabinet naar aanleiding van de inmiddels ontvangen Tweede en Eerste Kamervragen met de gevraagde 'appreciatie' van de uitspraken zal komen. In ieder geval mag worden verwacht dat het kabinet zal ingaan op de gevolgen van het arrest Varkens in Nood voor de Awb.

\section{Conclusies}

Samengevat kan worden geconcludeerd:

1. In haar uitspraak van 14 april 2021 heeft de Afdeling een veel te ruime broek aangetrokken en ervoor gezorgd dat aan art. 6:13 Awb een te beperkte toepassing wordt gegeven. Met een wetswijziging kan de tijdelijke werkwijze overigens wel worden 'recht' getrokken.

2. Haar uitspraak van 4 mei 2021 berust naar mijn mening op een onjuiste lezing van het arrest. Het Hof doet helemaal geen uitspraak over de toegang tot de bestuursrechter voor een niet-belanghebbende die een zienswijze heeft ingediend. Met een wetswijziging die de voorlopige werkwijze van de Afdeling codificeert, wordt de wetgever gevraagd om terug te komen op zijn uitdrukkelijke wens om procedures te voorkomen tegen overheidsbesluiten zonder dat de procederende partij een belang heeft dat rechtstreeks bij dat besluit is betrokken.

3. Het kabinet is aan zet maar zal daar wel wat tijd voor nodig hebben.
33. Het gaat dan om art. 56, tweede lid, ('in afwijking van artikel 8:1 Awb') juncto art. 54, tweede lid, onder d (het gs-besluit inzake goedkeuring van het bestemmingsplan) juncto art. 27 , eerste en tweede lid, van de Wet op de Ruimtelijke Ordening. 